\title{
Experimental Coinfection of Chicken Anemia Virus and Mycoplasma gallisepticum Vaccine Strains in Broiler Chicks
}

-Author(s)

\section{Prezotto CF' \\ Marin $\mathrm{SY}^{\prime}$ \\ Araújo TS" \\ Barbosa FO \\ Barrios PR" \\ Gomes AM" \\ Peconick API \\ Resende $\mathrm{M}^{\prime}$ \\ Sousa RV}

Martins NRS'

Escola de Veterinária, Universidade Federal de Minas Gerais, Brazil.

" Departamento de Veterinária, Universidade Federal de Lavras.

\section{ABSTRACT}

This study aimed at determining the clinical and pathological effects of the coinfection of young SPF chickens with chicken anemia virus (CAV) and Mycoplasma gallisepticum (MG) vaccine strains. The clinical signs, gross and microscopic lesions were determined after the experimental coinfection broilers with a CAV genotype 1 vaccine strain given intraperitoneally on the first day of age and a MG F-strain vaccine given intranasally on the 8th day of age. The experimental groups included the negative control (group 1), a group infected with the MG F-strain vaccine (group 2), and a group coinfected with CAV and MG vaccines (group 3). Chicks were examined clinically and post mortem at 23 days of age, and gross and microscopic lesions of the trachea, thymus, and air sacs were compared among treatments (Kruskal-Wallis test). Infections were confirmed by PCR for specific genetic fragments of each agent in the target tissues. Mortality was only observed in chicks on group 3, with two deaths and more severe lesions in the trachea, thymus and air sacs compared with groups 1 and $2(p<0.01)$. Dead chicks presented reduced thymus and spleen size, hemorrhagic trachea with catarrhal exudate and partial obstruction, pericarditis, catarrhal airsacculitis, lungs with liquid and ascites. The surviving chicks in group 3 showed more severe respiratory changes than those in group 2, in addition to thymus and spleen size reduction. Results indicate the adverse effects of the coinfection of young chickens with MG F-strain and CAV genotype 1 vaccines.

\section{INTRODUCTION}

Mycoplasma gallisepticum (MG) may cause increased mortality, reduction in weight gain, a higher rate of condemnations in the processing plant due to airsacculitis in broilers, and reduction in egg production in layers, which result in very significant losses to the poultry industry (Evans et al., 2005; Ley, 2003; Lütticke, 1997; Nascimento and Pereira, 2009; Yashpal et al., 2004). However, MG may cause a much more serious disease if associated with other respiratory agents, such as other bacteria and viruses (Yashpal et al., 2004; Couto et al., 2015). The chicken anemia virus (CAV) is an immunosuppressive agent that may predispose chickens to primary and secondary infections, mainly by affecting the bone marrow and thymus, thus compromising the immune response and health of poultry (Brentano, 2009; Toro et al., 2009; Gallardo et al., 2012; Silveira et al., 2013).

Important poultry-producing regions are densely concentrated, and occasionally farms have poor biosecurity. Live vaccines, including those against CAV and MG strains, are commercially available and have been used for the prevention of diseases. This study aimed at evaluating the clinical signs and the gross and microscopic lesions in young chickens 
Prezotto CF, Marin SY, Araújo TS, Barbosa FO, Barrios PR, Gomes AM, Peconick AP, Resende M, Sousa RV Martins NRS

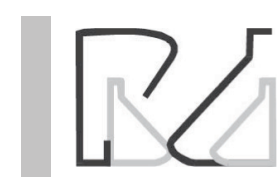

experimentally coinfected with commercial vaccine strains of MG and CAV. For this purpose, chicks were administered with the $\mathrm{F}$ strain of Mycoplasma gallisepticum (MG) in coinfection or not with a chicken infectious anemia virus (CAV) genotype 1 vaccine strain.

\section{MATERIALS AND METHODS}

\section{Chickens}

Certified specific pathogen free (SPF) chicken eggs (VALO, Uberlandia, Brazil) were incubated and hatched (Premium Ecologica, Brazil). Chicks were housed in an experimental facility in an isolated room. No other birds were present at the isolation unit. Fifteen chicks were randomly assigned to three treatments with five chicks in each. The birds received water and feed without any growth promoter or anticoccidial drug ad libitum. The experiment employed the adequate numbers of experimental animals for approval by the Ethics Committee (CEUA, UFMG).

\section{CAV}

A live attenuated phylogenetic group 1-type vaccine was reconstituted to obtain $10^{2.3}$ tissue culture infective doses $50 \%\left(\mathrm{TCI}_{50 \%}\right)$ per $\mathrm{mL}$.

\section{Mycoplasma gallisepticum}

A live attenuated MG F strain-type vaccine was reconstituted and cultured in Frey's medium (Frey et al., 1968) until obtaining a density of $3 \times 10^{5}$ CFU/0.1 $\mathrm{mL}$.

\section{Experimental protocol}

Chicks were administered the MG F-strain vaccine of on day 8 , in coinfection or not with a chicken infectious anemia virus (CAV) genotype 1 vaccine strain, given on the first day of age. The experimental groups were housed in cages in an isolation room with controlled air supply, independent water and food supply and restricted access.

Day-old SPF chicks were hatched and randomly divided into three groups of five birds each (Table 1). All CAV inoculations were administered intraperitoneally on the first day of age and MG inoculations given intranasally on the eighth day of age. At 23 days of age, all birds were euthanized, submitted to full necropsy, and the liver, spleen, thymus, and trachea were collected for histopathology and thymus and trachea for the investigation of CAV or MG by PCR. Considering that the infection by Mycoplasma gallisepticum strains may
Experimental Coinfection of Chicken Anemia Virus and Mycoplasma gallisepticum Vaccine Strains in Broiler Chicks

be evaluated in the trachea, especially during the acute stage of infection previous to the period needed for an antibody response (typically 21 days) to be detectable in all birds (Levisohn \& Dykstra, 1987), the isolation or detection by molecular methods is most successful during the acute stage of infection (Hyman et al., 1989). In addition, the duration of the experiment was reduced to a minimum in view of the risk of field CAV challenge.

Table 1 - Experimental groups.

\begin{tabular}{|c|c|c|}
\hline Group & Treatment & Infection \\
\hline 1 & Negative control & None \\
\hline 2 & MG-infected & $\begin{array}{l}\text { Day 8: Chicks were given the MG F-strain } \\
\text { vaccine containing } 3 \times 10^{13} \mathrm{CFU} / 0.1 \mathrm{~mL} \text {. }\end{array}$ \\
\hline 3 & CAV plus MG & $\begin{array}{l}\text { Day zero: At hatching, day-old chicks were } \\
\text { given live attenuated genotype } 1 \mathrm{CAV} \text { vaccine } \\
\left(0.2 \mathrm{~mL} / 10^{2.3} \mathrm{TCID}_{50 \%}\right) \text { intraperitoneally; } \\
\text { Day 8: After CAV at day zero, chicks were } \\
\text { given the MG F-strain vaccine containing } \\
3 \times 10^{13} \mathrm{CFU} / 0.1 \mathrm{~mL} \text { intranasally. }\end{array}$ \\
\hline
\end{tabular}

\section{Lesion score}

At necropsy, gross lesions were scored by adapting previously described score systems (Kogut et al., 1994; Leigh et al. 2012; Nunoya et al., 1987), with modifications as follows:

- Trachea: 0 - no significant alteration; 1 - mucus; 2 - mucus, thickening and localized hyperemic mucosa; 3 - catarrhal exudate, extensive thickening and generalized hyperemia of the mucosa; 4 - caseous exudate, generalized hyperemia, hemorrhage, partial and/or complete obstruction of the trachea, asphyxiation and death.

- Air sacs: 0 - no alteration; 1 - light opacity and increase in thickness; 2 - moderate increase in thickness and opacity and light accumulation of catarrhal exudate; 3 - severe increase in thickness, blisters and large accumulation of catarrhal exudate (foam); 4 - severe increase in thickness and fibrin deposition (caseous deposition).

- Thymus: 0 - no alteration; 1 - discrete reduction in lobe size; 2 - moderate reduction in lobe size; 3 - severe reduction and absence of a few lobes on both sides of the neck; 4 - complete atrophy of all lobes.

Conventional bacteriology of chicks to investigate the presence of Escherichia coli in the liver was performed in MacConkey agar (aerobiosis) at necropsy, in view this is the most common secondary infection after M. gallisepticum. E. coli infection would 
Prezotto CF, Marin SY, Araújo TS, Barbosa FO, Barrios PR, Gomes AM, Peconick AP, Resende M, Sousa RV Martins NRS

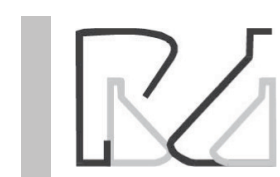

interfere with the interpretation of $M$. gallisepticum expected lesions.

\section{DNA extraction}

Total DNA extraction from tissues (thymus or trachea) was performed using silicon dioxide and sodium iodide (Boom et al., 1990; Vogelstein and Gillespie, 1979). DNA extracts were stored at $-20^{\circ} \mathrm{C}$ until use. Qualitative and quantitative DNA analyses were performed determining optical density in a spectrophotometer (NanoVue ${ }^{\circledR}$, GE Healthcare, UK) at 260 and $280 \mathrm{~nm}$ wavelengths.

\section{Oligonucleotide primers}

The two sets of primers used in the CAV PCR were previously described (Marin et al., 2010): CAVMGF 5'CCTGTTCCGACACATTGA3', corresponding to nucleotides 1444 to 1461, and CAVMGR 5'TATGGCCTCTGCCTGTTA3', corresponding to nucleotides 2119 to 2136 . The genomic position of nucleotides in the CAV DNA matched the Cuxhaven-1 strain (GenBank M55918.1) sequence. Primers used for the detection of MG were, as recommended by the Office International des Epizooties, MG-14F 5' GAGCTAATCTGTAAAGTTGGTC3' and MG-13R 5'GCTTCCTTGCGGTTAGCAAC3' (OIE, 2008).

\section{PCR amplification}

The CAV PCR protocol was described elsewhere (Marín et al., 2010), using a $5 \mu \mathrm{L}$ aliquot of each total DNA obtained from the thymus. Reactions were performed in $50 \mu \mathrm{L}$ volumes containing $200 \mathrm{ng}$ of DNA, 1X buffer (200 mM Tris-HCl pH 8.4, $500 \mathrm{mM}$ $\mathrm{KCl}), 0,4 \mathrm{mM}$ of dNTP, $2 \mathrm{mM}$ of $\mathrm{MgCl}_{2}, 1 \mu \mathrm{L}$ of each primer at $10 \mathrm{pmol}, 1 \mathrm{UI}$ of Taq Polymerase (Platinum Taq DNA Polymerase, Invitrogen, USA) and 18,2 Mili-Q ultrapure water q.s.p. For the MG PCR protocol, a $5 \mu \mathrm{L}$ aliquot of each tracheal total DNA sample was employed, using $50 \mu \mathrm{L}$ reaction volumes containing $35.75 \mu \mathrm{L}$ Mili-Q water, $10 \mathrm{X}$ buffer $(200 \mathrm{mM}$ tris- $\mathrm{HCl}$ $\mathrm{pH} 8.4,500 \mathrm{mM} \mathrm{KCl}), 1 \mathrm{mM}$ of dNTP, $0.5 \mu \mathrm{L}$ of each primer at $20 \mathrm{pmol} / \mu \mathrm{L}, 0,25 \mathrm{UI}$ of Taq Polymerase and $2 \mathrm{mM}$ of $\mathrm{MgCl}_{2}$.

\section{Histopathology}

Tissue samples were processed within 48-hour of fixation, sectioned, and placed in labeled cassettes for histotechnical preparation. Paraffin tissue blocks were cut into $5-\mu \mathrm{m}$ thickness and sections were placed onto glass slides and stained with hematoxylin and eosin, according to the laboratory routine protocol.
Experimental Coinfection of Chicken Anemia Virus and Mycoplasma gallisepticum Vaccine Strains in Broiler Chicks

\section{Statistics}

Statistical analysis of gross lesions scores of the trachea, air sacs and thymus was performed according to the Kruskal-Wallis test.

\section{RESULTS}

No changes were observed regarding clinical signs of birds of all groups. However, two deaths (40\%) were observed on day 16 on group 3, sixteen days after the inoculation of CAV and eight days after the inoculation with MG.

Necropsies of chicks of group 3 that died on day 16 revealed atrophic thymus, reduced spleen size (with whitish areas), hemorrhagic trachea with catarrhal exudate that partially obstructed the air passage (score 4), pericarditis, catarrhal airsacculitis, and lungs with liquid and ascites. Twenty-three days after CAV and 15 days after MG infections (23 days of age), significant differences in the analysis of the gross lesions of the trachea $(p<0.01)$, air sacs $(p<0.01)$ and thymus $(p=0.001)$ were observed in group 3 compared with groups 1 and 2 (Figures 1, 2, and 3). The air sacs (Fig. 2 ) were macroscopically more compromised in chicks of group 3 relative to groups 1 and $2(p<0.01)$. Severe thymus atrophy was observed 23 days after CAV infection in all birds infected with the CAV vaccine strain (group 3), while the thymuses of chicks in groups 1 and 2 remained unchanged ( $p=0,001)$ (Fig. 3 ). In contrast, no significant differences in gross changes were observed when comparing groups 1 and 2 . Escherichia coli was not isolated in the liver, indicating exclusive M. gallisepticum infection.

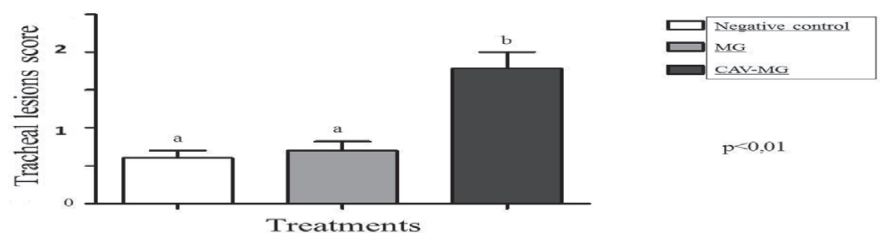

Figure 1 - Gross lesions score on the trachea as observed at necropsy of chicks administered a F-type vaccine strain of Mycoplasma gallisepticum (MG) at day 8, in coinfection or not with a chicken infectious anemia virus (CAV) genotype 1 vaccine strain given at first day of age. Chicks were examined at 23 days of age. White bar group 1(negative control); Gray bar MG group 2; Black bar CAV+MG group $3(p<0.01)$.

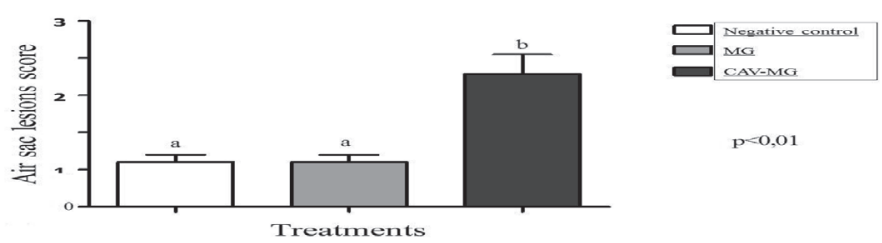

Figure 2 - Gross lesion score of the air sacs, as observed at the necropsy of chicks given CAV at day zero, MG at day 8 and examined at 23 days of age. White bar group 1 (negative control); Gray bar MG group 2; Black bar CAV+MG group $3(p<0.01)$. 
Prezotto CF, Marin SY, Araújo TS, Barbosa FO, Barrios PR, Gomes AM, Peconick AP, Resende M, Sousa RV Martins NRS

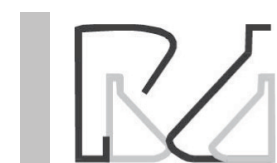

Experimental Coinfection of Chicken Anemia Virus and Mycoplasma gallisepticum Vaccine Strains in Broiler Chicks

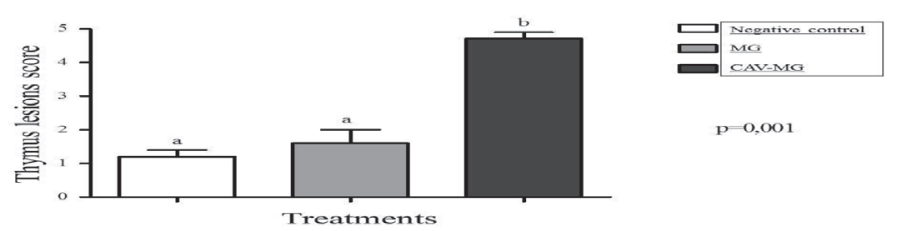

Figure 3 - Gross lesion score of the thymus as observed at the necropsy of chicks given CAV at day zero, MG at day 8 and examined at 23 days of age. White bar group 1 (negative control); Gray bar MG group 2; Black bar CAV-MG group $3(p<0.01)$.

At histopathology, the tracheas of chicks in group 1 presented normal epithelium, with cilia and goblet cells (Figure 4) and no changes were observed in thymus, liver and spleen. However, in the trachea of chicks in group 2, the epithelium was thinner, with shortened cilia in three birds (3/5); however, the other two birds presented fewer changes and more uniform distribution of the epithelium and normal presence of cilia (Figure 5). Chicks in group 3 showed the most evident changes in the tracheal epithelium, which was thinner, with increased number of goblet cells and sparse to absent cilia cover (Figure 6).
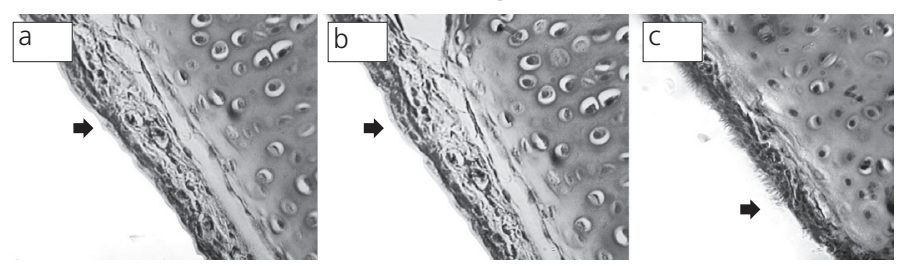

Figure 4 - Tracheas of the negative control chicks (group 1). All birds showed normal epithelium with cilia (black arrows) and goblet cells (H\&E).

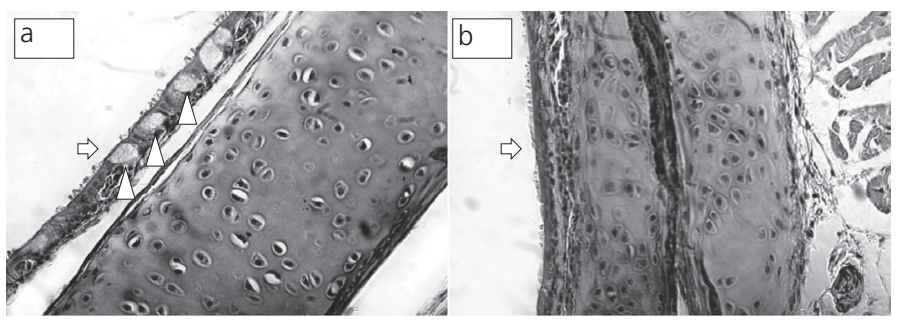

Figure $\mathbf{5}$ - Tracheas of the F-type Mycoplasma gallisepticum vaccine infected chicks (group 2). The trachea shows moderate changes, absence of cilia (a and b, white arrows) in the affected area and hyperplasia of goblet cells ( $a$, white arrowheads) (H\&E).
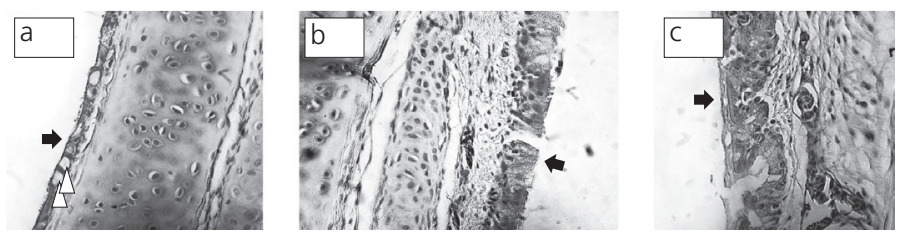

Figure 6 - Trachea of chicken anemia virus - CAV (hatching day) plus F-type Mycoplasma gallisepticum vaccine (day 8) infected chicks (group 3). Tracheas with pseudostratified epithelium with reduced thickness, increased number of large goblet cells ( $a$, white arrowheads) and scarce to absent cilia coverage (a, b and c, black arrows).

Regarding the molecular evaluation, CAV DNA was investigated in the thymus and trachea and detected only in the thymus of all chicks in group 3, but in none of the birds in groups 1 and 2. MG DNA was detected in the trachea of chicks in groups 2 and 3. Chicks in group 1 were negative for both MG and CAV DNA.

\section{DISCUSSION}

The severity of coinfection resulted in two deaths in chicks on group 3 (40\%). The primary infection with CAV eight days before the MG infection, may have immunocompromised the chicks and allowed a more severe secondary $M G$ infection of the chicks in group 3. The lesions observed, compared with the other two groups (Figures 1, 2 and 3), demonstrate that the coinfection tended to increase the severity of gross lesions and resulted in significantly $(p<0.01)$ more severe microscopic lesions of chicks in group 3 (Fig. 1). Immunosuppressive diseases usually negatively affect chickens of the poultry industry by increasing the susceptibility to opportunistic infections by viruses and bacteria (Lutticken, 1997; Balamurugan \& Kataria, 2006). Among the known immunosuppressive agents, CAV stands out for its worldwide occurrence, not only in commercial poultry, but also in SPF chickens (Schat, 2003; Balamurugan \& Kataria, 2006), backyard chickens (Barrios et al., 2009), as well as contaminates poultry vaccines (Barrios et al., 2012). CAV presents tropism for T-lymphocytes, rendering the cellular immune response ineffective, especially in young chickens, by destroying CD8+ T cells (Adair et al., 1993; Adair, 2000; Brentano, 2009), disabling the protection against intracellular agents. Through a facultative intracellular infection, MG can cause a systemic infection and evade the immune response (Vogl et al., 2008; Santos et al., 2009).

The severe thymus atrophy observed 23 days after CAV vaccine infection indicates a potential risk in case of biosecurity failure when chicks are maintained close to vaccinated breeders. In addition, the proximity of chicks to breeders vaccinated against CAV and MG F-strain may result in infection, resulting in severe immunosuppressive and respiratory disease, and potential increase in mortality.

Gaunson et al. (2000) showed that CD8+ T cells response plays an important role in the susceptibility to infection with Mycoplasma gallisepticum, as lymphocytes are the main target of CAV (Adair et al., 1993; Adair, 2000; Brentano, 2009). In our experiment, the primary CAV infection on day one may have allowed more severe MG infection, as demonstrated by more severe respiratory lesions in group 3 (Fig. 2).

Although the single MG infection (group 2) did not result in clinical disease, chick performance was not evaluated, and negative effects on these parameters cannot be discarded. Microscopically, rarefaction of 
Prezotto CF, Marin SY, Araújo TS, Barbosa FO, Barrios PR, Gomes AM, Peconick AP, Resende M, Sousa RV Martins NRS

\section{Experimental Coinfection of Chicken Anemia Virus and Mycoplasma gallisepticum Vaccine Strains in Broiler Chicks}

cilia and altered goblet cells were found, which are microscopic lesions also described in other studies (Leigh et al., 2012; Murakami et al., 2002; Nunoya et al., 1987).

The negative isolation of $E$. coli in liver may be associated with the high quality of the experimental chicks, which were specific-pathogen free, and the experimental housing conditions, which may have reduced spread and challenge. However, natural field conditions, with the possibility of challenge with $E$. coli resulting in a different outcome, possibly with more severe lesions and higher mortality due to the associated colibacillosis.

CAV (Schat, 2003) and MG (Ley, 2003) infections are widely distributed in the poultry industry worldwide, and live vaccines against these pathogens are used in Brazil. This study has shown, through the analysis of gross and microscopic lesions and confirmatory molecular detection, that the coinfection with CAVMG vaccine strains may have important health consequences, at least in young chickens. Natural coinfection of CAV or MG with other bacteria and viruses in the field are considered common (McNeily et al., 1995; Kleven, 1998; Zanella et al., 2001, Toro et al., 2009). It was previously reported that the MG F-strain vaccine may cause disease in the upper respiratory tract of chickens, which is possibly exacerbated when a concomitant secondary infection is present (Lin \& Kleven, 1982; Yoshida et al., 2000). Natural coinfections may occur in the field, under appropriate conditions, with vaccine strains, as well as with wild and more virulent strains, potentially causing more significant productivity losses (Balamurugan \& Kataria, 2006; Javed et al., 2005). Vaccines against CAV in breeders and MG in layers are commercially available in Brazil and the impact of the respective diseases may be reduced through vaccination. The correct vaccination of flocks must take into account bird age, vaccine strain, and dose, and should also consider the possibility of accidental coinfection. Vaccination protocols should ideally establish adequate distances among flocks, especially when very young chicks are housed nearby. The results of the present study demonstrate the synergic pathological effects of CAV-MG vaccine strains in coinfection, indicating the need to employ biosecurity strategies for vaccination in order to prevent the spread into susceptible flocks.

\section{REFERENCES}

Adair BM. Immunopathogenesis of chicken anemia virus infection. Developmental of Comparative Immunology 2000;24:247-255.
Adair BM, McNeilly F, McConnell CDG, McNulty MS. Characterization of surface markers present on cells infected by chicken anemia virus in experimentally infected chickens. Avian Diseases 1993;37:943-950.

Balamurugan V, Kataria JM. Economically important non-oncogenic immunosuppressive viral diseases of chicken-current status. Veterinary Research Communications 2006;30:541-566.

Barrios PR, Marin Sandra Y, Rios RL, Pereira CG, Resende M, Resende JS de , et al. A retrospective PCR investigation of avian Orthoreovirus, chicken infectious anemia and fowl Aviadenovirus genomes contamination in commercial poultry vaccines in Brazil. Arquivo Brasileiro de Medicina Veterinária e Zootecnia 2012;64:231-235.

Barrios PR, Marin SY, Resende M, Rios RL, Resende JS, Horta RS, et al. Occurrence of chicken anemia vírus in backyard chickens of the metropolitan region of Belo Horizonte, Minas Gerais. Revista Brasileria de Ciência Avícola 2009;11(2):132-138.

Boom R, Sol CJ, Salimans MM, Jansen CL, Wertheim-van Dillen PM, et al. Rapid and simple method for purification of nucleic acids. Jounal of Clinical Microbiology 1990;28(3):495

Brentano A. Anemia infecciosa das galinhas. In: Berchieri JR A, Silva EN; Fabio JD, Sesti L. Zuanaze, MAF. Doença das aves. 2nd ed. Campinas: Editora Fundação APINCO de Ciência e Tecnologia Avícolas; 2009. p.735-762.

Evans RD, Trites JD, Cochrane RL. Field evaluation of tylosin premix in layers previously vaccinated with a live Mycoplasma gallisepticum vaccine. Avian Diseases 2002:46(1):208-214.

Frey $\mathrm{ML}$, Hanson RP, Anderson DP. A medium for the isolation of avian Mycoplasmas. American Journal of Veterinary Research 1968;29:21632171.

Gallardo RA, van Santen VL, Toro H. Effects of chicken anaemia virus and infectious bursal disease virus-induced immunodeficiency on infectious bronchitis virus replication and genotypic drift. Avian Pathology 2012;41(5):451-458

Gaunson JE, Philip CJ, Whithear KG, Browning GF. Lymphocytic infiltration in the chicken trachea in response to Mycoplasma gallisepticum infection. Microbiology 2000;146:1223-1229.

Gomes AM. Caracterização molecular de isolados de micoplasmas da avicultura industrial de Minas Gerais e Espirito Santo [thesis]. Belo Horizonte (MG): Universidade Federal de Minas Gerais; 2013.

Goryo M, Okada K. Histopathology in chicks dually inoculated with chicken anemia virus and Marek's disease virus at various ages. Proceedings of the International Symposium on Infectious Bursal Disease and Chicken Infectious Anemia. Rauischholzhausen. Germany; 1994. p.392-405.

Javed MA, Frasca S Jr, Rood D, Cecchin K, Gladd M, Geary SJ, et al. Correlates of immune protection in chickens vaccinated with Mycoplasma gallisepticum strain GT5 following challenge with pathogenic $M$. gallisepticum strain R(low). Infection and Immunity 2005;73(9):54105419.

Kleven SH. Mycoplasmas in the etiology of multifactorial respiratory disease. Poultry Science 1998;77:1146-1140.

Kogut MH, Tellez GI, McGruder ED, Hargis BM, Williams JD, Corrier DE e al. Heterophils are decisive components in the early responses of chickens to Salmonella enteritidis infections Microbial Pathogenesis 1994;16(2):141-151.

Hyman HC, Levisohn S, Yogev D, Razin S. DNA probes for Mycoplasma gallisepticum and Mycoplasma synoviae: application in experimentally infected chickens. Veterinary Microbiology 1989;20(4):323-338. 
Prezotto CF, Marin SY, Araújo TS,

Barbosa FO, Barrios PR, Gomes AM,

Peconick AP, Resende M, Sousa RV

Martins NRS

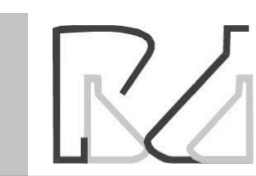

Experimental Coinfection of Chicken Anemia Virus and Mycoplasma gallisepticum Vaccine Strains in Broiler Chicks
Ley DH. Mycoplasma gallisepticum infection. In: Saif YM, Barnes HJ, Fadly AM, Glisson JR, McDougald LR, Swayne DE. Diseases of poultry. Ames: lowa State University Press; 2003. p.722-744.

Leigh SA, Branton SL, Evans JD, Collier SD. Effect of infection route and concurrent infectious bronchitis virus vaccination on Mycoplasma gallisepticum disease pathology in an experimental model. Avian Pathology 2012;41(5):497-503.

Levisohn S, Dykstra MJ. A quantitative study of single and mixed infection of the chicken trachea by Mycoplasma gallisepticum. Avian Diseases 1987;31:1-12.

Lin MY, Kleven SH. Egg transmission of two strains of Mycoplasma gallisepticum in chickens. Avian Diseases 1982;26(3):487-495.

Lütticken D. Viral diseases of the immune system and strategies to control infectious bursal disease by vaccination. Acta Veterinaria Hungarica 1997;45(3):239-249.

Marin SY, Barrios PR, Rios RL, Resende M, Resende JS, Santos BM, et al. Molecular Characterization of Contaminating Infectious Anemia Virus of Chickens in Live Commercial Vaccines Produced in the 1990s. Avian Diseases 2013;57(1):15-21.

McNeilly F, Smyth JA, Adair BM, McNulty MS. Synergism between chicken anemia virus (CAV) and avian reovirus following dual infection of 1-dayold chicks by a natural route. Avian Diseases 1995;39(3):532-537.

Murakami S, Miyama M, Ogawa A, Shimada J, Nakane T. Occurrence of conjunctivitis, sinusites and upper region tracheitis in japanese quail (Coturnix coturnix japonica), possibly caused by Mycoplasma gallisepticum accompanied by Cryptosporidium sp. Infection. Avian Pathology 2002;31(4):363-370.

Nascimento ER, Pereira VLA. Micoplasmoses In: Di Fabio J, Rossini LI. Doenças das aves. Campinas: Fundação APINCO de Ciência e Tecnologia Avícolas; 2009. p.485-496.
Nunoya T, Tajima M, Yagihashi T, SannaiS. Evaluation of respiratory lesions in chickens induced by Mycoplasma gallisepticum. Nippon Juigaku Zasshi 1987:49:621-629.

Santos SB, Nascimento ER, Faccini JLH, Barreto ML, Pereira VLA. Potentially pathogenic mycoplasmas in the external ear of clinically normal cattle in southeast Brasil: first report. Brazilian Journal of Microbiology 2009:40:455-457.

Schat KA. Chicken infectious anemia. in diseases of poultry. 11th ed. In: Saif YM, Barnes HJ, Fadly AM, Glisson JR, McDougald LR, Swayne DE, editors. Diseases of poultry. Ames: Iowa State University Press; 2003. p. 182-202

Smyth JA, Moffett DA, McNulty MS, Todd D, Mackie DPA. Sequential histopathologic and immunocytochemical study of chicken anemia virus infection at one day of age. Avian Diseases 1993;37(2):324-338.

Toro H, van Santen VL, Hoerr FJ, Breedlove C. Effects of chicken anemia virus and infectious bursal disease virus in commercial chickens. Avian Diseases 2009;53:94-102.

Vogl G, Plaickner A, Szathmary S, Stipkovits L, Rosengarten R, Szostak MP. Mycoplasma gallisepticum invades chicken erythrocytes during infection. Infection and Immunity 2008;76(1):71-77.

Yashpal SM, Devi PP, Sagar MG. Detection of three avian respiratory viruses by single-tube multiplex reverse transcription-polymerase chain reaction assay. Journal of Veterinary Diagnostic Investigation 2004; 16:244-248.

Zanella A, Dall'Ara P, Lavazza A, Marchi R, Morena MA, Rampin T, et al. Interaction between Marek's disease virus and chicken infectious anemia virus. In: Schat KA, Morgan RM, Parcells MS, Spencer JL, editors. Current progress on Marek's disease research. Kennett Square: American Association of Avian Pathologists; 2001. p.1119. 